\title{
Erratum to: Exploratory analysis of rain days in central Sudan
}

\author{
Nadir Ahmed Elagib
}

Published online: 26 November 2010

(C) Springer-Verlag 2010

Erratum to: Meteorol Atmos Phys (2010) 109:47-59

DOI 10.1007/s00703-010-0088-6

The online version of this article unfortunately contained a mistake. On page 56 (left column, lines 3 and 4 of the text), minus signs appeared for the rates of warming of air during the daytime and nighttime for $\mathrm{El}$ Gedaref. The corresponding rates should be $0.28^{\circ} \mathrm{C}$ decade ${ }^{-1}$ and $0.18^{\circ} \mathrm{C}$ decade ${ }^{-1}$.

The online version of the original article can be found under doi: 10.1007/s00703-010-0088-6.

N. A. Elagib ( $\square)$

Department of Civil Engineering \& Architecture,

University of Bahrain, P.O. Box 32038, Isa Town,

Kingdom of Bahrain

e-mail: elagib@hotmail.com 